(๑) James Thornton 2019. Legal Studies $\odot 2019$ Society of Legal Scholars. Cambridge University Press. This is the author's version of the work. It is posted here for private research and study, not for redistribution. The definitive version is published in Legal Studies (Cambridge University Press), available at: https://doi.org/10.1017/lst.2019.31

\title{
Is Publicly Funded Criminal Defence Sustainable? Legal Aid Cuts, Morale, Retention and Recruitment in the English Criminal Law Professions.
}

James Thornton

Nottingham Law School, Nottingham Trent University, Nottingham, UK

James.thornton@ntu.ac.uk

This article examines how continued reductions in fee levels for criminal legal aid work affect recruitment and retention in the English publicly funded criminal defence profession. Data from 29 qualitative interviews with English defence solicitors and barristers are analysed to explore the impact of these reductions on recruitment of new lawyers and retention of current lawyers. On the basis of these findings, also building on research conducted by lawyer professional associations, I argue that a combination of cuts to legal aid, the resulting working patterns and low morale has led to a position where the criminal defence profession, as we know it, is unsustainable.

Keywords: Criminal Justice; Practice, Profession \& Ethics; Defence Lawyers; Legal Aid; Morale; Recruitment

My sincere thanks to Mark Telford, David Gurnham, Jonathan Doak and the anonymous peer reviewers for their very helpful comments on earlier drafts. I am also very grateful to my interviewees for taking the time to share their stories with me. 
(c) James Thornton 2019. Legal Studies @ 2019 Society of Legal Scholars. Cambridge University Press. This is the author's version of the work. It is posted here for private research and study, not for redistribution. The definitive version is published in Legal Studies (Cambridge University Press), available at: https://doi.org/10.1017/lst.2019.31

\section{1 - INTRODUCTION}

Of all the legal disciplines, criminal law is probably one of the most well-known. Public references to other fascinating points of law, pale in comparison to the deluge of crime thriller novels, TV shows and news reports about criminal law. Yet, this is not reflected in the number of law students who enter the criminal defence professions, nor the size of those professions generally. Most law graduates take jobs outside law entirely. ${ }^{1}$ Of those who do take legal jobs, the majority do not take jobs in criminal law. ${ }^{2}$ Most law students' experiences of criminal law start, and end, with their compulsory Criminal Law module. The Law Society of England and Wales reports a "looming crisis" in the number of criminal law duty solicitors, with an average age of $47 .{ }^{3}$ Who exactly, their report makes us ponder, is going to replace these people when they retire? Similarly, the latest England and Wales Bar Council survey reports that over a third of criminal barristers are considering other careers and a third say they would leave the Bar if they could. Half do not feel able to cope with the stress of their work. ${ }^{4}$ Those figures represent a deterioration in sentiments, relative to the previous (2013) survey.

This article seeks to complement these findings, by using qualitative interview data from a variety of criminal lawyers (at various levels of seniority) to examine in greater depth why these morale, recruitment and retention issues in the criminal defence professions exist. Previous work and my own methods are considered first, followed by analysis and discussion of the present study's qualitative data. I argue that these feelings of discontent (and resultant recruitment and retention issues) are the result of an environment which has become progressively more unpleasant to work within. This environmental deterioration has been facilitated in large part by financial reductions: directly and, more importantly, indirectly. Directly, in the sense that being paid less is demoralising and low earnings discourage recruits and hinder retention, and indirectly, in the sense that financial issues require defence lawyers and others in the process to work in ways that are frustrating and demoralising, discouraging recruits and hindering retention. Whilst every lawyer has their own personal reasons for leaving, considering leaving or rejecting a career in criminal defence, the above direct and indirect factors were found across various roles, experiences and locations in the lawyers in this study.

\section{2 - RELEVANT FINDINGS FROM PREVIOUS WORK AND THE CURRENT STUDY'S METHODS}

Issues of morale, both in the legal professions generally and in the criminal defence professions particularly, are well known and widely reported.

\footnotetext{
${ }^{1}$ There were 15,896 law graduates in 2017 compared with a (fairly stable) number of 5719 registered trainee solicitors and 474 pupil barristers.

See: Law Society Trends in the solicitors' profession Annual Statistics Report 2017 (June 2018) and Bar Standards Board Pupillage Statistics (2018), available at https://barstandardsboard.org.uk/mediacentre/research-and-statistics/statistics/pupillage-statistics/

${ }^{2}$ In 2017, there were 16,435 practicing barristers. Although it is not compulsory for barristers to disclose practice areas, the Bar Standards Board estimated for the Ministry of Justice that a minority (around 5000) of barristers specialise in criminal law. Similarly, of the circa 10,000 law firms in England and Wales, 2,262 held criminal legal aid contracts in 2015 - Ministry of Justice Litigators Graduated Fees Scheme and Court Appointees Equality Statement (2017).

${ }^{3}$ Law Society Criminal duty solicitors: a looming crisis (2018), available at https://www.lawsociety.org.uk/policy-campaigns/campaigns/criminal-lawyers/. A duty solicitor is a solicitor who agrees to be available "on-call" to assist at the police station and/or magistrates court for those suspects/defendants who do not currently instruct a specific solicitor. For many, it is the first port of call.

${ }^{4}$ Bar Council Barristers' Working Lives 2017 (May 2018), available at https://www.barcouncil.org.uk/media/661503/working_lives_-_final.pdf
} 
() James Thornton 2019. Legal Studies @ $\odot 2019$ Society of Legal Scholars. Cambridge University Press. This is the author's version of the work. It is posted here for private research and study, not for redistribution. The definitive version is published in Legal Studies (Cambridge University Press), available at: https://doi.org/10.1017/lst.2019.31

A broad malaise can be seen from research on publicly funded legal work. ${ }^{5}$ Sommerlad, writing in 2001 , reported "decline in income, greatly increased work burdens, high stress and low morale" among legal aid (including criminal) solicitors. ${ }^{6}$ Sommerlad blamed a philosophy of New Public Management in the public sector and predicted that "legal aid factories" - ie firms which allegedly, (according to hostile views in government and the media) ${ }^{7}$ perform high volume, but low quality, publicly funded work, would be the winners. Sommerlad argued these successes would come at both the expense of clients (because the work is allegedly poor) and the taxpayer (because cases are run in ways which maximise profits rather than efficiency). ${ }^{8}$ The committed "political" firms would be the losers (i.e. those who do legal aid work mainly for its political impact rather than to make money) That said, the level of service clients and the taxpayer can reasonably expect from necessarily limited public funds is a complicated distributive justice question, given that this may come at the expense of other government services, which could benefit those same individuals. As Lipsky points out, unless done to a massive extent, increasing funds tends to increase the quantity of clients served, but not the quality of service to individuals. ${ }^{9}$ This does not dispute the impact on morale, but it does suggest the relationship between resources and service is complex.

In terms of morale generally, Moorhead found similar concerns voiced in a survey of 270 legal aid solicitors firms in $2004 .{ }^{10}$ One respondent noted "it will be too late to get young blood into criminal defence work before a desperate shortage hits". Another said morale was "rock bottom". ${ }^{11}$ Moorhead also noted the existence of "escape routes" for the low morale legal aid lawyer to take, further aggravating the issue. They need not stay doing legal aid. ${ }^{12}$ At the same time, Moorhead noted that for those who do stay, "the economic pressure to bill more on the same rates" may incentivise "behaviour which practitioners indulge in but also recognise as distasteful, unprofessional, improper or dishonest."13

In criminal legal aid specifically, Kemp interviewed 24 defence solicitors alongside exploratory observation of magistrates courts and custody suites. She also had data from structured interview surveys conducted by IPSOS MORI of 1142 court users. ${ }^{14}$ Kemp's work highlighted that some of the

\footnotetext{
${ }^{5}$ And, in the background, there is perhaps an even broader conflict in the profession generally between commercial capitalist and professional values. An issue as fundamental as how we should live. See A Bradney 'How to live: aristocratic values, the liberal university law school and the modern lawyer' (2011) 2 Web JCLI. Although beyond the scope of this work, it is worth pointing out that the issues discussed here may operate in addition to these broader structural issues in the legal professions generally, which would aggravate any impact. ${ }^{6}$ H Sommerlad " "I've lost the plot": an Everyday Story of the Political Legal Aid Lawyer' (2002) 28 JLS 335 , 360.

${ }^{7}$ Ibid, p341.

${ }^{8}$ Ibid, p341,p360. To what extent these firms exist (in 2002, or now) is debateable. Sommerlad certainly believed they did (pp341-342), and other research supports this: see eg M McConville et al Standing Accused (Oxford: OUP, 1994) and (more recently), D Newman Legal Aid Lawyers and the Quest for Justice (Oxford: Hart, 2013) and P Gibbs and F Ratcliffe Criminal defence in an age of austerity: Zealous advocate or cog in a machine? (Transform Justice, 2019). As we shall see, interviewee comments in the current study referred to ethically dubious (not to mention inefficient) actions by some individuals, but stopped short of alleging widespread malpractice at firm level.

${ }^{9}$ M Lipsky Street Level Bureaucracy: Dilemmas of the Individual in Public Services (New York: Russell Sage, 1980).

${ }^{10}$ R Moorhead 'Legal Aid and the Decline of Private Practice: Blue Murder or Toxic Job?' (2004) 11(3) International Journal of the Legal Profession 159.

${ }^{11}$ Ibid, p175.

12 Ibid, p180.

${ }^{13}$ Ibid, p182.

${ }^{14}$ V Kemp Transforming Legal Aid: Access to Criminal Defence Services (Legal Services Research Centre 2010) p18.
} 
() James Thornton 2019. Legal Studies @ 2019 Society of Legal Scholars. Cambridge University Press. This is the author's version of the work. It is posted here for private research and study, not for redistribution. The definitive version is published in Legal Studies (Cambridge University Press), available at: https://doi.org/10.1017/lst.2019.3

issues previously discussed were clearly still live, such as demoralisation about the future ${ }^{15}$ and the presence and use of exit routes out of the profession to more profitable work. ${ }^{16}$ Similarly, respondents in Kemp's research noted that, even then, junior lawyers had began to drift away: "It's so hard to recruit now because low-level people are transferring out [of criminal defence services] and they are going in to the government, the CPS or the Courts Service." ${ }^{\prime 7}$ Newman's work with three law firms also found issues with morale. Newman went as far as to categorise legal aid criminal defence lawyers as "alienated workers" 18 and even "neurotic" - in the Freudian sense of being mentally disturbed.${ }^{19} \mathrm{~A}$ recent report based on interviews with a number of judges identified reductions in money, morale and professional status of defence advocates as a barrier to good advocacy work in the criminal courts and, the judges thought, a contributing factor to advocates avoiding criminal practice in favour of civil. ${ }^{20}$ Most recently, Law Society focus groups of criminal lawyers found that recruitment was so bad that participants referred to themselves as "dinosaurs heading for extinction" 21 .

In essence, previous work suggests a perceived issue in morale, recruitment and retention in the criminal defence professions, reported both by lawyers themselves and the judges who adjudicate their cases. I seek to build upon the work above in several senses, first, by providing an up-to-date qualitative window into the way both criminal solicitors and barristers (at various levels of seniority and practice) experience their work and, second, why (and how) this might lead to the quite dramatic levels of dissatisfaction and retention/recruitment issues reported in the above work and the current study. In other words, this work backs up earlier findings in terms of morale, recruitment and retention issues (in the sense that it provides further and more up-to-date evidence for their existence) and then explores further why and how these issues come about, by examining the experiences of a varied group of defence lawyers. My argument is that finance is both a direct, but also an indirect key driver in these issues. In making this argument, I draw upon insights from qualitative interviews with 29 practicing defence lawyers with various levels of expertise. The sample comprised 16 barristers, 12 solicitors and 1 very experienced paralegal (who interviewed with a solicitor colleague they had worked with for many years). These interviews were conducted as part of a broader project into the working practices of criminal lawyers, of which the particular discussion in this article reports an important part. ${ }^{22}$ It is hoped that these one-to-one interviews can complement the practitioner focus groups research above, by providing more details into some of the themes discussed through the benefits of a more private discussion. ${ }^{23}$

Solicitors were recruited with an invitation letter sent to criminal legal aid firms on the Ministry of Justice's list in southern England. This was a successful recruitment strategy. However, because the pool of practicing Criminal Barristers is much smaller, ${ }^{24}$ a different approach was taken to recruit barrister participants. Letters were sent to the treasurers of each of the four Inns of Court explaining

15 Ibid, p109.

${ }^{16}$ Ibid, p107.

${ }^{17}$ Kemp, above n14, p107

${ }^{18}$ D Newman 'Are lawyers alienated workers?' (2016) 22 European Journal of Current Legal Issues.

${ }^{19}$ D Newman 'Are lawyers neurotic?' (2018) 25(1) International Journal of the Legal Profession 3.

${ }^{20}$ G Hunter, J Jacobson and A Kirby Judicial Perceptions of the Quality of Criminal Advocacy (2018), 4.1. One judge provided a personal example of leaving the criminal barrister profession: by their becoming a judge!

${ }^{21}$ BVA BDRC Civil and Criminal Solicitors' Views on LASPO (September 2018) p48.

${ }^{22} \mathrm{~J}$ Thornton The Impact of Criminal Legal Aid Finance Reduction on the Work of Defence Lawyers $(\mathrm{PhD}$ Thesis, University of Southampton, 2018).

${ }^{23}$ Interviews were conducted in-person or via telephone. Open-ended questions were asked about their work, in the context of recent and proposed funding cuts and industrial action. Some transcription changes were made for easier reading: for example, repeated words, filler discussion and interviewer replies of "yes", and so on are omitted. Italicised text within square brackets is a paraphrase of something an interviewee said (to save space). Non-italicised text in square brackets is to clarify how or what was said. Unique expressions were modified to preserve anonymity.

${ }^{24}$ Above n2. 
() James Thornton 2019. Legal Studies @ $\odot 2019$ Society of Legal Scholars. Cambridge University Press. This is the author's version of the work. It is posted here for private research and study, not for redistribution. The definitive version is published in Legal Studies (Cambridge University Press), available at: https://doi.org/10.1017/lst.2019.3

the project and the need for participants. Three of the Inns agreed to advertise the research to their members. A similar approach was taken with the Criminal Bar Association, which agreed to advertise the research in their weekly newsletter for several months. Participants were also encouraged to nominate potentially interested colleagues. One interviewee referred me to a large Facebook group of criminal lawyers, whose administrators allowed a post asking for interested participants. Further willing interviewees were also located by the endeavours of personal and professional contacts working at the Bar.

\section{3 - ANALYSIS AND DISCUSSION}

The discussion here can be categorised into three broad themes (and each is dealt with here in its own section, one by one). Firstly, how low finance (alongside some other systemic issues) caused frustrations with working life. Secondly, how both those frustrations themselves and low finance negatively influenced morale in general. Thirdly, how low finance, the frustrations themselves and low morale together impact the future of the criminal defence professions in terms of recruitment and retention. However, these themes are not shut off from one another; they relate/cascade into one another and all also have a common root: finance (albeit that finance is not necessarily the exclusive cause). The data suggest that whilst low finance is indeed a key issue in terms of recruitment and retention (as work from the professional associations contends), it is more than just a simplistic case of: "I want to be paid more money to buy nice things and the fact that I am not means I will leave/not join the criminal defence profession". Of course, financial concerns operate in this way too (nobody works for free and having more money is pleasant), but it is not the only way in which they operate. Rather, whilst low finance does operate in this direct way (which we shall see when considering recruitment and retention), it also operates in an indirect, secondary, way (influencing frustrations with working life and morale, which themselves both influence retention and recruitment). In other words, financial constraints also make doing the job unpleasant, by forcing individuals to work in particular ways they deem improper or frustrating (3.1) and generally making individuals feel negative about their prospects through financial stress and feeling undervalued (3.2). Indeed, this indirect way may in fact be more influential than the direct way. Hence, the cascading effect of both direct and indirect factors makes what might in isolation seem to be tolerable issues of not being paid quite enough, into an unbearable deal-breaker for many. The diagram below summarises this proposed relationship: 


\section{Figure - Direct and Indirect Contributors to Recruitment and Retention Issues}

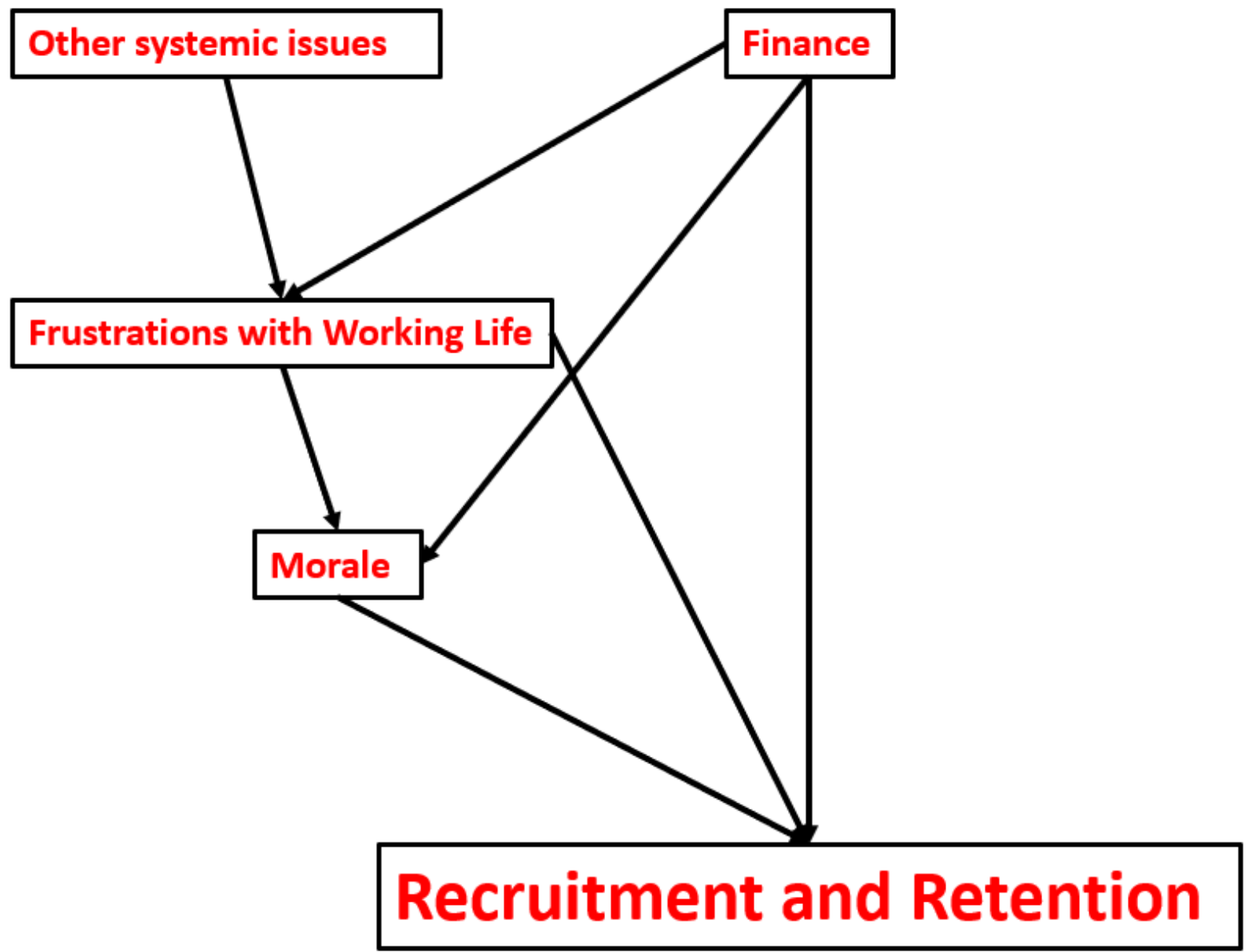

The following sections examine how each of these (frustrations, morale and recruitment/retention) operate in more detail. However, in brief, my argument is that finance influences how appealing it is to become or remain a criminal defence lawyer ("recruitment and retention") in three inter-related ways. First, "finance" (in the sense of "how much money defence lawyers and firms receive for work done"), has a direct impact on "recruitment and retention" (in the obvious sense that nobody works for free etc.). Second, "finance" combines with a variety of other systemic issues (some themselves caused by austerity in a more general sense, eg problems working with the Crown Prosecution Service, which many interviewees argued was under-resourced too). This creates or contributes to "frustrations with working life": an unpleasant and stressful working life for defence lawyers. This itself has a further negative impact on "recruitment and retention", simply because it makes the job day-to-day more unpleasant and difficult and, therefore, less appealing to do or continue doing. Thirdly, that these "frustrations with working life", combined with stresses related more directly to "finance" (eg struggling to pay bills, student loans or run a solvent firm), contribute to low "morale" (ie generally feeling negative and disillusioned). This itself also hinders "recruitment and retention", because (put crudely) if the job makes you and your colleagues sad, it is less appealing to do or remain doing. Hence, whilst finance hinders recruitment and retention, it is not just in the most obvious way of "wanting to be paid more money".

\section{1 - Frustrations with working life}

Both barristers and solicitors reported a great deal of frustration with their working lives. Within this, a key issue was a perceived lack of time on the part of both professions (which often affected the other one) to prepare cases to the standard they thought was required - largely as a business coping mechanism for reductions in fees paid by government and the way in which work done is assessed (via fixed fees for particular kinds of work, rather than hourly rates). Other concerns related to the 
() James Thornton 2019. Legal Studies @ $\odot 2019$ Society of Legal Scholars. Cambridge University Press. This is the author's version of the work. It is posted here for private research and study, not for redistribution. The definitive version is published in Legal Studies (Cambridge University Press), available at: https://doi.org/10.1017/lst.2019.3

workings of the courts and prosecution services and late payments by the government (Legal Aid Agency) or instructing law firms.

On the issue of lack of time for solicitors to prepare, Barrister B, whilst outlining the problem, said:

I've got solicitors that work all night. They'll stay in the office 'till 11 and go completely above and beyond the call of duty, but then I've got solicitors that don't do that and just leave it... I quite often will have clients where they won't have been in to see their solicitor, there's no instructions and it's for me to sit down on the morning of trial and say: "OK what do you say happened" and start from the beginning... they just don't have the manpower to give each case what it deserves.

Hence, this is not a case of inter-professional mudslinging: even the solicitors who don't stay up late into the night are presented here as joint victims of a lack of staff and financial cuts, rather than being at fault.

Barrister interviewees described the stress and frustration this could cause on the day of trial in terms of playing "catch up" or "winging it":

Barrister K: Once I got there I could cross-examine the first prosecution witness and catch up with the case as I went, which is what you do in that situation.

Barrister L: if you're unlucky you'll be sort of winging it at the court trying to get 15 minutes here or there to ask [the client] questions to try and make sure you're able to ask the right questions of the witness and keep the trial on track. Things get done, but just not done properly [laughs], or sometimes not done... people are trying to cut all the corners they can.

On the solicitor side, there was much agreement, for example:

Solicitor A: you either do the job properly and lose money or you don't do the job properly and the alternative perhaps for some is to work evenings and weekends as a matter of ordinary routine, but you end up so tired that you can't really do it.

Solicitor E: we really do still do it properly, but a lot of firms now, they'll pick up the case and you're talking minimal minimal work on it. They're not really looking at any of the legal issues, they're just sending all the papers to the barrister: "you sort it out". The barristers, it's going from one to the other to the other and no-one's really getting to grips sometimes with the very important issues that are going on, so then you can get to the day of trial and actually you realise "oh, there's this really important issue

An apparent lack of time on the part of litigators to prepare adequately is clearly a source of frustration to them directly, but also has a knock-on effect on their advocate colleagues. Further, as Solicitor E suggests above, barristers too were reported (from both solicitor and barrister interviewees) to be suffering from similar issues in terms of their own ability to prepare cases on tight margins, for example:

Barrister H: They got the papers at 6.00pm; they have to be in court tomorrow morning at 9.00am. Some of these matters can be complicated. 
(c) James Thornton 2019. Legal Studies (๑) 2019 Society of Legal Scholars. Cambridge University Press. This is the author's version of the work. It is posted here for private research and study, not for redistribution. The definitive version is published in Legal Studies (Cambridge University Press), available at: https://doi.org/10.1017//st.2019.31

Barrister J contrasted this with work for a defendant paying privately, doing things "properly", and also illustrating a coping mechanism for low finance and how that impacts time available for each case:

The fact that I was privately funded meant I got the papers at the first appearance. I could meet the client for a conference. We could prepare a proper defence. We had a video of what had happened at the scene. The prosecution barrister, who was very experienced, got the papers the night before and hadn't been able to look through them, hadn't been able to plug any of the gaps in his case, and it was that that made the difference. It wasn't my brilliant advocacy - well, partly my experience - but mostly it was the fact that I'd been able to prepare the case properly and that was all I was doing on that day. I wasn't running around trying to make ends meet by doing 16 other things - because that's how barristers keep doing legal aid work.

Hence, there were two reasons given for this lack of time. First, because the barrister sometimes received the details late themselves (due to solicitors also lacking time to prepare) and second, because the barrister had to do so much else in order to make a profit. This perceived lack of time available for lawyers to do their job in a way they considered "proper", added stress to their lives and made them fear for adverse consequences on the fairness of proceedings. There are also issues for the administration of justice more generally. A constant feeling of not having enough time to do things, of having to "wing" important work etc. could result in miscarriages of justice or delays, as things which could have been done before court are done on the day or even (as Barristers K and L noted) as the lawyer goes along. The judiciary's robust approach to adjournment applications in the magistrates court in particular suggests that trials will often go ahead, ready or not, ${ }^{25}$ increasing the risk of miscarriages of justice in such a case. Barrister K's experiences in the Crown Court suggest similar issues there too: you cannot ask for an adjournment or anything of that nature. If it's listed for trial, that's what's going to happen.

The source of these issues of lack of time etc. was considered both as a direct result of under-funding of their own profession, and as a knock-on effect from underfunding of the other profession. However, frustrations were not only caused by internal financial issues. Interviewees argued that other actors in the process, such as the courts and prosecution services, exacerbated these impacts although many of these issues could be linked to austerity measures in a more general sense too.

For example, Barrister B described their experiences in the magistrates courts as chaotic:

\footnotetext{
${ }^{25}$ Criminal Practice Directions 2015, Consolidated with Amendment No.8 [2019] EWCA Crim 495 at [24C]. The tone and language here is illuminating: [24C.7] makes clear that the starting point is the trial proceeds, that courts should "resist" granting adjournments and consider them a "last rather than first resort". It concludes: "any suggestion of a culture readily permitting an opportunity to correct failures of preparation should be firmly dispelled". [24C.9] goes on to require judges to "rigorously scrutinise" adjournment applications and have regard to the principle that "delay brings the criminal justice system into disrepute". [24C.10] accepts that the consequence of refusing an adjournment may be "that the defendant is unable to explore an issue", but nonetheless considers this "may be a just consequence of inadequate preparation. Even in the absence of fault on the part of either party it may not be in the interests of justice to adjourn, notwithstanding that an imperfect trial may be the result." For the Crown Court: Criminal Practice Directions XIII: Listing [F8] - [F10] is similarly clear cut: "Once a trial date or window is fixed, it should not be vacated or moved without good reason. Under the Criminal Procedure Rules, parties are expected to be ready by the trial date... requests to adjourn or vacate fixtures or trial windows must be referred to the Resident Judge for his or her personal attention".
} 
(c) James Thornton 2019. Legal Studies @ 2019 Society of Legal Scholars. Cambridge University Press. This is the author's version of the work. It is posted here for private research and study, not for redistribution. The definitive version is published in Legal Studies (Cambridge University Press), available at: https://doi.org/10.1017/lst.2019.3

I did a year in the magistrates court and it was hilarious. It's just chaos. There's just so many cases coming through that you're really up against it.

Nor was the Crown Court any better:

I've got a sexual assault, where the complainant's quite vulnerable... and it's had three of four trial dates... and it's just not been met, it's been going on now for over a year.

Other issues with courts were more practical in nature: courts not being maintained (a contributor to low morale for everyone involved):

Barrister H: they're disgusting and I think it's a bit of an embarrassment. If you go to [London Court X] or [London Court Y] or [London Court Z]. God! Some of those places I don't think have ever been cleaned. The lifts don't work. The bathrooms are broken. If the facilities were in better condition it would probably just make the whole process easier for people.

Solicitor B: they've got chairs that are broken, they've got things that don't work, issues with flooding. No one's investing in the courts themselves. No one's investing in the court staff, who are demoralised and don't answer the phone etc.

A similar story was presented about the prosecution service. Some barrister interviewees in particular could give a useful perspective on this since many of them did prosecution work too. For example,

Barrister M: it's not their fault because they're being, effectively, set up to fail: there aren't enough people, never mind enough good people, to actually make the system work... I prosecuted on my own a five-handed drugs case some years ago, and it was five weeks of sheer, unadulterated hell.

Barrister K: There are parts of the country where it barely works at all. [City A] is particularly bad and so indeed is [City B - in a different part of the country], where you can be certain that important bits of the case are missing and you quite often don't even know what they are and then there will be a sudden panic and a flurry of stuff uploaded just before the case... the whole thing feels like it's run on the seat of your pants.

The language and level of discontent in the above quotes is striking. These issues with the courts and prosecution (services which defence lawyers must work with every day as part of the job), can all serve to make the working environment frustrating, unpleasant and difficult.

A final particular cause of frustration amongst barristers was the reluctance of the Legal Aid Agency (LAA) and some solicitors' firms to pay money owed for work done. For example,

Barrister D: They just don't pay... I mean to be honest, they're a bit like a shady backstreet garage! I've just won a case [against the LAA] in front of the costs master at the High Court, which has taken over two years to get the money out!

Barrister J: We've got a pretty good set of fees clerks. And then they chase the money. But if you're not really well run then you can take six, nine, twelve months to get paid for a case. I get paid roughly within six months, but that's pretty good generally. 
() James Thornton 2019. Legal Studies @ $\odot 2019$ Society of Legal Scholars. Cambridge University Press. This is the author's version of the work. It is posted here for private research and study, not for redistribution. The definitive version is published in Legal Studies (Cambridge University Press), available at: https://doi.org/10.1017/lst.2019.3

The level of distrust between defence lawyers and the LAA not only led Barrister D to look upon them as a "shady backstreet garage", but also meant that barristers felt the need to employ a dedicated clerk and, in some cases, take the agency to court. Barrister J's situation illustrates the scale of the problem well: even being paid 6 months late is considered "pretty good"!

Many barristers also complained about payments from solicitors firms. However, there is a conflict here. Barristers are somewhat discouraged from making a fuss, because their solicitors ultimately send them their future work, as Barrister C noted:

you might get your money but [chuckles] you'll end up out of work because you'll have upset your firm. It's always been a problem at the Bar, but since the cuts have come in it's become much much worse.

Barrister $\mathrm{F}$ too noted this, but also suggested this was aggravated by other potential sources of revenue paying late.

Barrister F: The culture of solicitors not paying junior advocates,- sometimes not for a while, sometimes not for-ever - and the slug-like pace of the state institutions (both the probation service and those who instruct prosecutors) being very very slow to pay is as much a factor as the fact that fees were being cut because after all if you are struggling to make a rent payment or if you're trying to plot month to month how you're going to run your household budget, the fact the fee might be a bit lower is probably a bit less important than the fact that you may or may not get it. ${ }^{26}$

Barrister F referred to numerous examples of not being paid for years (or not at all).

Hence, we can see a variety of frustrations with working life as a criminal lawyer - many of which involve finance, either directly (in the case of having to cut corners in preparation to make business solvent) or indirectly, in the sense of lack of finance or funding in other areas leading to late payments or problems with courts and prosecutors. ${ }^{27}$ There will be other sources of frustration too, e.g. problems with court security. ${ }^{28}$ These issues all take their toll on the attractiveness of the job directly (crudely: "this job is needlessly difficult day-to-day"), but they also impact on morale generally, which is a factor for causing recruitment and retention issues in itself (crudely: "doing this job makes me sad. I don't want to do it"). We will now examine how financial issues and these frustrations with working life impact morale in more detail.

\section{2 - Morale}

Many of the interviewees reported a fall in overall morale both as a result of insufficient payment generally and as a result of some of the frustrations outlined in the previous section (supporting the previous research into legal aid lawyers suggesting this was a problem). ${ }^{29}$ "Morale" here is used in the

\footnotetext{
${ }^{26}$ Although of course one reason why money is paid late may be because defence firms' and government departments' margins are tight.

${ }^{27}$ See also J Thornton 'The Way in Which Fee Reductions Influence Legal Aid Defence Lawyer Work: Insights from a Qualitative Study' (2019) 46 JLS, discussing the impact of cuts in terms of perverse financial incentives for lawyers on plea advice, case type and reviewing evidence.

${ }^{28}$ See eg Law Society Gazette Court security guard who told female lawyer 'spread your legs' is suspended (2018), available at https://www.lawgazette.co.uk/news/court-security-guard-who-told-female-lawyer-spreadyour-legs-is-suspended/5068452.article

${ }^{29}$ Kemp, above n15; Sommerlad, above n6, p356; Moorhead, above n10, p175: one respondent called their work "a totally thankless task".
} 
() James Thornton 2019. Legal Studies @ $\odot 2019$ Society of Legal Scholars. Cambridge University Press. This is the author's version of the work. It is posted here for private research and study, not for redistribution. The definitive version is published in Legal Studies (Cambridge University Press), available at: https://doi.org/10.1017/lst.2019.3

general sense of feeling negative, disillusioned etc. and is therefore slightly different to the above section (although frustrations with working life themselves contribute to low morale, they are not the same thing). Whilst the previous section dealt with how doing the job itself is difficult, this section addresses a more general sense of how one feels (positive or negative) about that job.

In terms of morale generally, perhaps the most succinct summary of the morale problem was a spontaneous comment made at the end of Barrister E's interview:

Interviewer: Right, I mean we've kind of gone through everything I wanted to specifically-

Barrister E: I bet we have! I feel like I've unloaded... it's cathartic! It's like going to the psychiatric couch... I feel, I've sort of unloaded full rant on you!

In general terms, the impression given was of a concerningly low level of morale amongst interviewees and their peers. It appears that morale is undermined by both the low pay in itself as well as the demands of the profession.

Barrister K illustrates this well:

The fees are so low that the financial anxiety is now impossible. It was difficult before and now it's impossible because you're always living... I used to live with this knot of tension in my chest, which was always really about money and would I be paid then and did I dare go on holiday at that point because in the summer a lot of very good briefs come through because a lot of other people are on holiday and it's not a very nice way to live and it's very stressful.

Plus, I have to say, it's quite depressing, I mean, particularly the sex cases. It's absolutely ghastly. It's very stressful work. I mean, to have to cross-examine a seven year old about why she's making up these wicked stories is no joke. So the money isn't enough to make up for that is what I'm saying.

The other issue is how the financial position places pressure on lawyers to do the job in a way they perceive to be improper. For example,

Paralegal A: because everybody's been ground down by various governments and what they've done to the legal aid system over the last 10 years in particular I think that goodwill to a large extent has gone and sadly what you have is almost a factory-like process of cases entering the system and going through and coming out the other end. And whilst everybody does their best, erm, it is [sigh] I dunno how to describe it, it is [pause] there are fewer cases that really get [pause]

Solicitor G: Proper treatment.

Paralegal A: Yes! Exactly.

Thus there is a clear connection between low pay itself affecting morale, but also that low pay making lawyers feel like they must work in an improper way - which is in itself demoralising. As Barrister B noted, even if this is resisted, it nonetheless has a negative effect on morale:

you're aware of it as "right, I'm doing my job properly but isn't this rubbish." 
() James Thornton 2019. Legal Studies @ 2019 Society of Legal Scholars. Cambridge University Press. This is the author's version of the work. It is posted here for private research and study, not for redistribution. The definitive version is published in Legal Studies (Cambridge University Press), available at: https://doi.org/10.1017//st.2019.31

Even one of Sommerlad's self-described "political" and committed legal aid lawyers eventually "lost the plot" as a result of financial pressure.$^{30}$ Everyone has a tipping point and the impact of finance reduction may be to push many to that point.

Two further excerpts provide more detailed examples of this in operation.

Barrister F: The advocate has been paid so piss poorly, is having such a shit time, that he or she just wants to go home. You throw up your hand, giving the impression that you know the system better than the client - which you probably do - and say "well it's all looking very negative isn't it? Perhaps you should reconsider your plea". And that happens at the margin cases, the pickpocketing or the low-lying Public Order Act offence. Where the junior advocate, who's thinking <fuck this, I've lept across London to do this brief, I dunno if I'm ever gonna get paid for it, when I started this brief was worth £150, now it's worth £75> [says] "you should just plead guilty I think." Now that is the sort of culture, the early cynicism instilled in advocates which, yes, I definitely did see a bit of: these prematurely warweary and cynical late 20-somethings who were just knackered and disillusioned.

Barrister $\mathrm{G}$ came to a similar conclusion, also noting how the prosecution side was not immune from the problems:

I think the state of morale across the criminal justice system is really low. The CPS in particular really struggle with the fee cuts on their side, so they now have a lack of bodies to do the work, but also a lack of incentive to do it properly and that is partly because they're stretched so thin, it's partly because there's just not enough money. And that all takes its toll on people just not feeling terribly enthusiastic about the job; not truly caring if they are going to stay late and do something that really needs doing, making sure that disclosure gets out on time etc. And it's the same for defence now, more recently, that you don't feel like the work you're doing is valued and so, like you say, when practitioners are faced with a decision, $A$ is in my client's interest, B is in my financial interest, a lot of people might say " $B$ " erm unfortunately. Simply because you don't get the recognition for the fact that you have sat up all night to prepare a particular case in a particular way or gone out of your way to do something that other people wouldn't necessarily do.

The low fees themselves are directly affecting morale here, but the way in which those fees sometimes encourage lawyers to work adds to this. The above suggests that finance impacts morale in direct ways, in the sense of "being poorly paid makes me struggle to make a living, which is stressful", but it also impacts morale in more indirect ways in the sense that it aggravates general difficulties associated with the job, such as the emotionally difficult nature of serious sex crime cases that Barrister $\mathrm{K}$ mentioned. If one is paid very little for doing something that is difficult and draining, this itself can impact morale. Similar indirect effects can be seen in the sense that many of the frustrations discussed which have a negative impact on morale are themselves created or contributed to by financial issues. The financial incentives in the system that Barristers $\mathrm{F}$ and $\mathrm{G}$ mentioned become more tempting if the lawyer involved is struggling to make a living. The fact that there is not enough time to do things "properly" is partly the result of needing to do such a high volume of work in the first place in order to run a solvent business. Such reports also raise concerning implications for the administration of justice more generally. The risks of miscarriages of justice from the phenomena

\footnotetext{
${ }^{30}$ Sommerlad, above n6, p356.
} 
() James Thornton 2019. Legal Studies @ $\odot 2019$ Society of Legal Scholars. Cambridge University Press. This is the author's version of the work. It is posted here for private research and study, not for redistribution. The definitive version is published in Legal Studies (Cambridge University Press), available at: https://doi.org/10.1017/lst.2019.3

reported by barristers $\mathrm{F}$ and $\mathrm{G}$ above are obvious. To what extent this occurs is not ascertainable from the current study's small sample, but the above quotes illustrate a compelling mechanism for it. ${ }^{31}$

The issues raised above do not paint a picture of a profession that is appealing to join or remain in. We shall now consider lawyer responses (in terms of this article's focus: recruitment and retention) to the above sections' themes and to low finance generally.

\title{
3.3 - Future of the professions
}

The future of the criminal legal aid defence professions matters. Fair criminal trials have long been accepted as an essential component of the rule of law for society (and with it, a civilised and free one), ${ }^{32}$ and for individuals as a fundamental human right. ${ }^{33}$ Effective criminal defence is an important element of that.$^{34}$ Unfortunately, as we shall see in this section, the response to the above issues by many lawyers is to move away from criminal law work: either entirely, or towards private paying clients (undermining fairness between defendants of different means). Interviewee comments also highlight some interesting potential problems in relation to the diversity of the legal professions generally.

Feelings of discontent were significant here and at times made for uncomfortable listening. For example Barrister $\mathrm{K}$ provides a short, but insightful, comment on how the frustrations above, low morale and low finance influences the future of the professions, but much the same was heard across the board:

\author{
It's hell and no one can really see any prospect of it improving, to be honest \\ $\cdots$ \\ Interviewer: So I mean, as far as you're concerned there is, at present, no real future for the \\ junior Criminal Bar?
}

\section{Barrister K: I can't see one, which is why I'm getting out.}

The main response was doing other kinds of work. Interviewees mentioned: privately funded criminal defence work; diversifying into other areas, such as prosecution or other areas of law and of course, as we just saw, leaving the professions entirely. Many also drew attention to problems with recruitment. There was also mention of a series of behaviours that could be termed "hobbyist criminal law" ie

\footnotetext{
${ }^{31}$ It is worth pointing out that it does accord somewhat with Newman's (n8) study on this issue of unethical practice, in another part of the country, albeit that that too is a very small sample of practitioners. The difficulty with finding large scale quantitative data on these issues is the depth of analysis required to unearth unethical conduct - which qualitative methods can provide, but by nature will likely have smaller and more focused samples of. We then face the further difficulty of unearthing a miscarriage of justice in the first place and then, thirdly, establishing a causative link between it and lawyers' behaviour. It is clear, however, that lawyers respond to financial incentives generally: P Fenn et al 'Standard Fees for Legal Aid, an Empirical Analysis of Incentives and Contracts' (2007) 59(4) Oxford Economic Papers 662, 678.

${ }^{32}$ See eg T Bingham The Rule of Law (London: Penguin, 2011) Ch9.

${ }^{33}$ See United Nations Universal Declaration of Human Rights 1948, General Assembly Resolution 217A, Art10 and (more locally) European Convention on Human Rights 1950, Art6(3)(c).

${ }^{34}$ Whilst of course it is debateable (particularly for comparatively trivial crimes) to what extent "effective criminal defence" always requires access to defence lawyers, very few would argue that all cases could be fairly conducted without them.
} 
() James Thornton 2019. Legal Studies @ 2019 Society of Legal Scholars. Cambridge University Press. This is the author's version of the work. It is posted here for private research and study, not for redistribution. The definitive version is published in Legal Studies (Cambridge University Press), available at: https://doi.org/10.1017//st.2019.3

almost leaving, but not quite, by diversifying so much that the lawyer involved only did the odd criminal case - for a mixture of goodwill/pro bono and intellectual stimulation.

PRIVATE WORK

Many interviewees discussed taking on more private work. E.g. Barrister J put their position particularly strongly:

The general run of the mill crime, at least defending, is not worth doing. So if I do criminal cases at the Crown Court, it's privately paid only now.

The difference in service was frankly explained:

You get somebody who's had the opportunity to prepare your case, to read your case, to advise you properly, like we used to - I mean, when I started, you had to turn up actually knowing your case rather than reading it on the train on the way there. It gives you a massive advantage.

Barrister J did not feel happy about this, but had accepted it was what had to be done to make a living.

Perhaps most tellingly of all, in an offhand comment, Barrister L revealed that not every barrister could count on doing this, only those who were "successful"...

Interviewer: And you can make a living off that ... off private work alone?

Barrister L: Some people can, you have to be successful, usually you have to have been at the job for a while

Crudely put, criminal lawyers who are "successful" (in the sense of being well-regarded enough in the market by clients and/or solicitors to attract this kind of work) can do private defence and only those who aren't have to do legal aid.

Similarly, for solicitors, almost everyone did some private work to a greater or lesser extent e.g.

Solicitor B: There's more private client work these days. A, because legal aid is more difficult to obtain and B, because frankly, my firm is a very well-regarded firm.

Hence, as far as some solicitors are concerned, private work is a pre-requisite of a financially sound criminal law solicitor's business and most interviewees also said there was significant competition for this work, because there was not that much of it around. For example,

Solicitor E: we try and get as much private work as we can because it's so much better paid, but the people who are in the criminal justice system are from a certain socio-economic background that generally cannot pay private fees.

Again, that phenomenon of the "successful" lawyer doing more private work raised by Barrister L appeared to be somewhat reflected here. As solicitor B put it, "well regarded" firms are the ones who can get the limited, lucrative private work. This illustrates an effect in terms of "recruitment and retention" (in the sense that, if done to a significant extent, it amounts to semi-leaving the legally aided defence profession). It can also be generally problematic in terms of the administration of justice. As Barrister J (amongst others) pointed out above, the difference in service between legally 
() James Thornton 2019. Legal Studies @ 2019 Society of Legal Scholars. Cambridge University Press. This is the author's version of the work. It is posted here for private research and study, not for redistribution. The definitive version is published in Legal Studies (Cambridge University Press), available at: https://doi.org/10.1017/lst.2019.31

aided and private work can be considerable. Lawyers can only run so many cases at one time. If private work assumes greater significance in the defence lawyer's caseload, there is less time for legal aid and a two-tier system between rich and poor. Of course, this might not be a problem: a lawyer taking on more private cases could mean they do fewer legal aid cases, but the ones they do have might not receive any lesser service. However, interviewees (eg Barrister J's comments above) suggested there $i s$ a difference in terms of time spent. It might further be said that there is a problem if it is the good or "well regarded" lawyers doing the private work and only the less good doing legal aid, but that is not clear-cut. What it means to be a "good" or "successful" lawyer (and whether this is equivalent to being "well regarded" by the market) is a matter of intense debate. ${ }^{35}$ In any event, many mentioned how (in spite of being able to do private work) they still did some legal aid for goodwill reasons, eg

Solicitor E: our responsibility to our local community is that we do legal aid work even though it's not very profitable.

Barrister O: I felt clients welcomed having a barrister from out of town, because of being an ethnic minority, I've found it comforts clients, they felt they could talk more freely, and also who was not part of, as they saw it, the local establishment. I have done it and I've known by doing it I'm going to be out of pocket. It's part of my commitment to social justice.

Shute et al's review of ethnic minorities in the criminal courts found a similar preference from surveyed defendants. There was a belief that confidence in the courts would be strengthened if more personnel from ethnic minorities were seen to be playing a part. ${ }^{36}$ Why might a client from an ethnic minority need to look further afield in order to find a barrister of their own background (if that is their preference)? The simple fact may be that it is because there are so few practising barristers from black and minority ethnic (BME) backgrounds. Statistics from the BSB suggest that (of 16,598 practising barristers in 2018) 2146, just under 13\%, come from a BME background.$^{37}$ It is regrettable that financial issues hinder access to this already very small pool (not all of whom necessarily practice crime either). Not every BME barrister can do this work for free and nor indeed should they be expected to.

Others mentioned how crime work was interesting and therefore they continued to do a little bit of it. For example,

Barrister L: I only do crime for interest because I make my living on the public law [laughs]. But I can tell you now that if my public law work dried up I would not be prepared to go and do crime full time legal aid... But that's... criminal legal aid work shouldn't be people's pastime, hobby or secondary things for people.

Again, this illustrates an effect in terms of "recruitment and retention" (in the sense that, if done to a significant extent, it amounts to semi-leaving the legally aided defence profession). Whether it is generally problematic in terms of the administration of justice is debateable. On the one hand, diverse practice may be a strength in providing lawyers with new skills and experiences, which can enhance their criminal practice. On the other hand, empirical work from three in-depth studies examining the

\footnotetext{
${ }^{35}$ See eg T Smith 'The "Quiet Revolution” in Criminal Defence: How the Zealous Advocate Slipped into the Shadow' (2013) 20(1) Int J of the Legal Profession 111.

${ }^{36}$ S Shute et al A Fair Hearing? Ethnic Minorities in the Criminal Courts (Abingdon: Routledge, 2011) p131.

${ }^{37}$ Bar Standards Board Practising Barrister Statistics (May 2019). Available at: https://www.barstandardsboard.org.uk/media-centre/research-and-statistics/statistics/practising-barristerstatistics/
} 
() James Thornton 2019. Legal Studies @ $\odot 2019$ Society of Legal Scholars. Cambridge University Press. This is the author's version of the work. It is posted here for private research and study, not for redistribution. The definitive version is published in Legal Studies (Cambridge University Press), available at: https://doi.org/10.1017//st.2019.3

effects of lawyer specialisation suggests that "specialists provide higher levels of quality than nonspecialists and that in absolute terms, the quality of nonspecialist advice is worryingly poor." 38 Further, as Barrister L hints at, if something is seen as "secondary" or as a pastime, it may receive less attention and of course, whilst the glamorous or complex case might be interesting enough to grab the hobbyist's attention, not every criminal case is intellectually stimulating.

A further problem is that the apparent evaporation of goodwill ${ }^{39}$, suggests that the permanence of this service cannot be guaranteed. In any event, often this was only possible because it was being subsidised by more profitable work elsewhere in the firm or barrister's practice (discussed further in the following section). Barrister $O$ provides an extreme example of this loss of goodwill in terms of solicitors they worked with, who had to, at best, join up with larger firms to sustain cuts and, at worst, went out of business:

I can say that a lot of ethnic minority firms of solicitors who would have sent me cases decided they couldn't tender on that basis and simply went out of the legal aid business altogether. So that's social provision in all parts of the country that just went...

Their [ethnic minority] client base would be relatively small, so there were lots of firms that had just one or two partners per practice. Many of those small firms would take on cases and defend/represent their client base and sometimes they'd sustain the reduction in profit or losses because you believed in their case. It wasn't just a business. When it's a sole practitioner, they're face-to-face with the community where something's gone wrong, a lot of wrongful arrests to do with drugs, say, that partner would have to face the families and say "yes, of course, I'll defend you"; whereas, if he was part of a firm of five or six partners, it's easier to say "well, I'd love to, but the partners won't let me."

This echoes the experience of one of Kemp's respondent solicitors: "we are in an ethnic minority area and people come to us because we are local and know what is going on... it is getting more difficult... I was overdrawn by $£ 50,000$ last year." ${ }^{40}$ Kemp's respondent clients also showed a clear preference for someone from "the same ethnic background as me"; "I want someone who understands my ethnic background and uses words I can understand." ${ }^{\text {11 }}$ Likewise, Shute et al.'s findings (already mentioned in terms of barristers) are equally applicable to solicitors. Confidence in the courts would be strengthened if more personnel from ethnic minorities were seen to be playing a part. ${ }^{42}$ Barrister O's comments suggest this is frustrated. The business model of the small firm of BME practitioners targeting a particular community who (understandably) want a lawyer they can relate to, is hindered by financial reduction. Of course, scale has benefits too - and presumably large firms also employ lawyers from these backgrounds - but as Barrister O points out, there is an issue in terms of losing connection with the issues faced by particular communities (such as in their wrongful drug arrests example) and, whilst some of these smaller ethnic minority firms consolidated with larger firms, others simply shutdown entirely.

\footnotetext{
${ }^{38}$ R Moorhead 'Lawyer Specialization - Managing the Professional Paradox' (2010) 32(2) Law \& Policy 226, p249.

${ }^{39}$ See in particular comments in section 3.2, above.

${ }^{40}$ Kemp, above n14, p110.

${ }^{41}$ Ibid, p97.

${ }^{42}$ Shute et al, above n36, p131.
} 
() James Thornton 2019. Legal Studies @ $\odot 2019$ Society of Legal Scholars. Cambridge University Press. This is the author's version of the work. It is posted here for private research and study, not for redistribution. The definitive version is published in Legal Studies (Cambridge University Press), available at: https://doi.org/10.1017/lst.2019.3

\section{DIVERSIFICATION}

Apart from private defence work, some barristers diverged into prosecution work as an alternative to legal aid defence. For example,

Barrister A: my practice has shifted to, I would say, $3 / 4$ prosecution work from when it used to be $3 / 4$ defence.

Barrister M would have been prepared to do $100 \%$ prosecution work if their preferred defence firms closed due to cuts:

I was looking at not doing any defence work at all at one point or at least not in any meaningful sense.

However, we should remember that it was also Barrister $M$ who described a significant case they had done for the CPS as "five weeks of sheer, unadulterated hell"! Prosecution work might seem a useful alternative in the abstract, but it would appear not to be immune from the morale issues presented earlier either. Barrister J identified a more pleasant solution for the lawyer involved: doing work that is both prosecution and private:

It's growing rapidly. There's a firm called [name], who are doing a lot of private prosecution work for a lot of banks.

Similarly, many solicitors had diversified from crime into other areas, to a greater or lesser extent, eg

Solicitor C: I'm doing about 50-50 crime-childcare. The benefit in childcare being it probably pays better than any other legally aided work.

So, there is a significant impact here: at the extreme end, we now have Barrister A spending $3 / 4$ of their total time doing prosecution work. This goes to the core issue of whether a publicly funded criminal defence profession is sustainable. ${ }^{43}$ The decisions and attitudes displayed by these comments suggest it may not be.

LEAVING

Lastly, diversification is one thing, but the nuclear option was perhaps most popular of all: either staying in legal practice, but doing non-criminal law work or leaving legal practice and doing something else entirely.

For example, Barrister C pointed out the (in their case, irresistible!) lure of alternatives:

Everyone continuously contemplates leaving. I don't know anyone who's adamant they're going to stay... Most junior members at the moment have either left the profession or are on secondment somewhere [eg, the Serious Fraud Office or Financial Conduct Authority].

Other barristers, such as Barrister F, left the profession entirely:

Most of my work was in legal aid work and the fact that the cuts were being made was a significant factor in my deciding to take another career. By the time I left, I was doing a pretty steady diet of Crown Court work, but the point at which that was properly remunerated and I could be certain of repayment, was just, it was like the Bob Dylan song, "It's just around the corner from you, but with truth so far off what good would it do"? It almost seemed like it might come about at some point and in the end, given the way the profession looked like it was going I just thought, "fuck it". I remember going to the Isle of Wight to go

\footnotetext{
${ }^{43}$ Alongside the issues raised by Moorhead's studies, above n38, in regards to specialists vs non-specialists.
} 
() James Thornton 2019. Legal Studies @ 2019 Society of Legal Scholars. Cambridge University Press. This is the author's version of the work. It is posted here for private research and study, not for redistribution. The definitive version is published in Legal Studies (Cambridge University Press), available at: https://doi.org/10.1017/lst.2019.3

to court. Once you get to Ryde, you're still on the wrong sodding side, so you've got to get a bus across the Isle of Wight to Newport and I didn't have enough money for the bus! That's what alcoholics call a moment of clarity! When you realise you're several years into a professional career and something's not quite right here.

Similarly, individual solicitors left criminal law - sometimes immediately and sometimes over a gradual period of increasing diversification:

Solicitor A: to cut a long story short, there came a point last year where I couldn't stack up doing the proper job on legal aid with having a business that was going to be commercially viable. So I personally went into other work.

Solicitor J: There's a lady, she used to be a full-time duty solicitor with us and she's leaving. She's doing regulatory work with various different bodies.

We had another lady about two years ago and she left to go and re-train to do insolvency law. Again, incredibly well qualified and very experienced criminal defence lawyer just decided there was no future.

This would seem to confirm the early prediction of Smith's respondents that the best "would leave crime in their droves". ${ }^{44}$ This extends beyond individuals though. Many pointed out that whole firms may "leave" in the sense that they just have to close down due to lack of profit or that they felt they were on their last chance $\mathrm{eg}^{45}$

Solicitor E: It's gonna be kind of shit or bust [sic] really. We're hoping that a few other [firms] might bow out, but it's gonna be tough... It's tough when we look at our figures and our property department's made 5 times the amount we have in one month.

Solicitor E later considered that their department closing was a very real possibility.

RECRUITMENT OF TRAINEES, PUPILS AND NEWLY QUALIFIED SOLICITORS AND BARRISTERS. Similar to leaving, is the declining proportion of law graduates opting to pursue a career in criminal law for the reasons discussed above, or who leave very early on for the reasons discussed above. Those involved in chambers recruitment often mentioned this issue. $\mathrm{Eg}$

Barrister G:

New entrants don't really want to do crime. I think that's the main problem! Most of the applicants we have now in our set are only interested in civil... Those who don 't go off to do civil often go in-house, we've had quite a lot of people who leave who for example go to one of the regulatory prosecutors, so the Nursing and Midwifery Council is quite a popular one.

Solicitor interviewees recounted similar problems. the issue was a mixture of not many students being interested and that firms would be unwilling/unable to take them on in any event:

\footnotetext{
${ }^{44}$ T Smith 'Justice for Sale: An Empirical Examination of the Attitudes of Criminal Defence Lawyers Towards Legal Aid Reform' (2014) Plymouth Law and Criminal Justice Review 1, p28.

${ }^{45}$ And recall also Barrister O's comments in the previous section.
} 
() James Thornton 2019. Legal Studies @ 2019 Society of Legal Scholars. Cambridge University Press. This is the author's version of the work. It is posted here for private research and study, not for redistribution. The definitive version is published in Legal Studies (Cambridge University Press), available at: https://doi.org/10.1017/lst.2019.3

Solicitor B: We're really at a nadir in terms of the quality of people the profession is now attracting. The firms haven't got the resources now to attract the best and the brightest.

Solicitor D pointed out that, irrespective of finance issues, new solicitors were inconvenient for a firm at the best of times:

We have to supervise the trainee solicitor as he or she acquires that experience, which is, bothersome... irritating... time consuming and annoying. So trainee solicitors are very unattractive.

Views from the perspective of recent barrister entrants reflected this. Certainly, the two recently finished pupil barristers I spoke to: Barristers I and $\mathrm{H}$ had no intention of staying in pure criminal legal aid themselves. Barrister $\mathrm{H}$ planned to use the experience as a springboard for a career in another area of law and Barrister I, whilst not abandoning criminal legal aid altogether, had already diversified (to [self-described] just under 20\% none-legal-aid-crime) and intended to diversify further into other areas. Barrister $\mathrm{H}$ also noted why one of their peers decided to leave, drawing out how it was not just the finance directly, but also the concurrent pressures of morale and the difficulties discussed in the first section of this article:

she goes "I'm sick of waking up at 7.00am and working until midnight, getting up and doing it again. I just don't want my life to be like this." And she didn't mention the money, to be fair. She said it's just too much. But then, it wouldn't be that much if there were more practitioners at the Bar, if they got paid better. It's wrong... You know, we really do - Monday through Friday, my routine is I get up at 7.00am. I'm in court till 6.00pm. I get my papers from my chambers. I get home about 7.00/8.00pm; have something to eat; start looking at my papers between 8.00 and $9.00 \mathrm{pm}$ and I usually spend two or three hours a night and I go to bed at midnight or 1.00am. Get up at 7.00am and do it again. I do that every single night. And Saturdays, I usually go to Saturday court, back by 3.00/4.00pm, do my papers. And I sleep Sunday [laughs]. And then Sunday night, I have to prep for Monday morning. And there's only so long you can do this for.

For solicitors, one of Solicitor J's former trainees made a similar choice:

We just had a young girl, she's 26 now, she's just qualified, she's leaving us to go and join another local firm doing family work. They're able to pay her a lot more and her future is going to be significantly better.

Respondents in Kemp's research noted that, even then, junior lawyers had began to drift away: "It's so hard to recruit now because low-level people are transferring out [of criminal defence services] and they're going in to the government, the CPS or the Courts Service." ${ }^{\prime 46}$ From the current research, we can now see that this has mutated further: into leaving criminal law entirely (perhaps due to the issues mentioned earlier in relation to the courts and CPS). Moreover, the lack of new recruits at the criminal bar and the increases in those departing soon after qualification carries implications for the future diversity of the Bar. As Morison and Leith found, starting out as a barrister without other (eg parental) income to assist in the early days is uniquely difficult at the best of times, due to the way the profession is structured ${ }^{47}$ Upon full qualification, there is no guaranteed salary and reputation needs

\footnotetext{
${ }^{46}$ Kemp, above n14, p107

47 J Morison and P Leith The Barristers' World and the Nature of Law (London: Open University Press, 1992) p25.
} 
() James Thornton 2019. Legal Studies @ $\odot 2019$ Society of Legal Scholars. Cambridge University Press. This is the author's version of the work. It is posted here for private research and study, not for redistribution. The definitive version is published in Legal Studies (Cambridge University Press), available at: https://doi.org/10.1017/lst.2019.3

to be built up (which takes time, during which one may not earn particularly well). Hence, for those from more modest financial backgrounds, the profession can be unappealing at the best of times. Interviewees made the same point. $\mathrm{Eg}$

Barrister B: My mum and dad kindly sent me 1100 a week for about 8 months to help me get going, but some people don't have that.

Barrister O: The role models have gone, especially for the ethnic minority youngster, or working class, to enter the profession of social legal services, because when I was head of chambers, I arranged specifically for young people at about the age they were trying to decide on their O levels and A levels to come and spend a week in chambers. And the numbers of ethnic minority youngsters who subsequently decided they wanted to become lawyers and have become lawyers was remarkable.

\begin{abstract}
And it's not just a race thing either. There were working class youngsters from parts of London who came along - white. I remember several who went home and told their parents there were barristers in chambers and some of them were black. They came and told me their parents couldn't believe it! So that changed the outlook of a lot of people.
\end{abstract}

Lawyers in this study identified a variety of what Moorhead termed "escape routes" 48 , which they seemed willing to take as a response to the financial and other issues outlined in this article. Although in some cases this was reluctantly so (because they considered the publicly funded criminal law professions to be socially worthy), nonetheless they were willing to do so if they had to. For some, this involved a move towards privately paid work (albeit still in criminal law), or prosecution work though private work in this area was felt to be in short supply and prosecution work carried its own financial and morale problems. Hence, many others went further, either leaving the legal profession entirely or putting their skills to use in non-criminal fields, such as working for (or against) financial and professional regulators (e.g. the Financial Conduct Authority and Nursing and Midwifery Council) or simply different areas like insolvency or family law. The recruitment side of things was similarly negative, with the lawyers reporting a two-sided problem: fewer applicants (because of the financial and other problems discussed here) and, for solicitors, fewer firms being able to take the financial and practical burden of trainees in any event. Of those who did remain in legal aid criminal work, many nonetheless tried to diversify, with some doing very little criminal legal aid work, often simply for goodwill or even intellectual amusement. None could see a future where it was the main or even a significant focus of their professional activities. These findings may also have wider implications than the individuals directly involved. High quality lawyers leaving for other areas runs the risk of a drop in quality for the future, with potential miscarriages of justice and inefficient running of the courts as a result. In addition, public confidence in the criminal justice system partly depends on it being representative of the country as a whole, not just the privileged, white, and male. ${ }^{49}$ The fact that criminal solicitors and barristers almost exclusively make up the pool of potential

\footnotetext{
Although not mentioned by interviewees in the current study, similar comments as for race and social background could be made about structural issues in relation to women at the Criminal Bar. See eg Western Circuit Women's Forum Back to the Bar (2018) which found that 2/3rds of those who left the Bar on the Western Circuit over a 6 year period were women and that the vast majority of women left mid-career (conversely, almost all the men who left over the same period became judges or retired). The recruitment and retention issues discussed in this article operate in addition to these structural barriers.

${ }^{48}$ Moorhead, above n10, p159.

${ }^{49}$ Shute et al, above n36, p131.
} 
() James Thornton 2019. Legal Studies @ $\odot 2019$ Society of Legal Scholars. Cambridge University Press. This is the author's version of the work. It is posted here for private research and study, not for redistribution. The definitive version is published in Legal Studies (Cambridge University Press), available at: https://doi.org/10.1017/lst.2019.31

salaried criminal judges,$^{50}$ underlines the importance of this. The judiciary is already poorly representative of the general population. ${ }^{51}$

\section{4-DISCUSSION}

Returning to first principles, pay can affect how satisfied someone is with their job. Money allows someone to buy more expensive things, live in nicer places, etc. The lawyers in this study reported that inadequate remuneration directly affected their willingness to work in the criminal defence profession on this basis. Nonetheless, there is a puzzle: many jobs are poorly paid and yet there is not quite the same crisis as there is for criminal lawyers. A recent Law Society survey, for example, put median average pay for non-partner criminal lawyers at $£ 42,500 .{ }^{52}$ Although their sample size is too low to draw much from this on its own, the comparison with other areas in the study is interesting: crime expectedly had a lower average than business and commercial property, but was either above or similar to other areas such as employment, family and probate. Yet, there is no similar crisis in terms of a very high average age of family, employment and probate lawyers, as there is for criminal duty solicitors. ${ }^{53}$ We have seen however, that there is more to finance in criminal defence than simply the amount a lawyer receives into their bank account each month being, in their view, inadequate (of course, many criminal solicitors will actually earn significantly less than the "Law Society Median", and which in any event says nothing about the earnings of criminal barristers).$^{54}$ Financial issues also operate indirectly. First, by forcing lawyers and law firms to work in particular ways, which are frustrating (section 3.1), second by impacting lawyers' earnings to the point that lack of money itself becomes a source of stress, in terms of paying bills and supporting one's more basic needs, lowering morale (section 3.2), and third by making businesses themselves (a separate issue from how much goes into monthly pay packets) financially unviable (section 3.3). The effect is multiplied because these things themselves also impact willingness to remain in the job. Having to work in ways which lawyers find frustrating, distasteful or improper (section 3.1), itself contributes to low morale (section 3.2), which itself affects willingness to do the job at all (section 3.3). Likewise, low morale from stress of paying bills etc. (section 3.2), affects willingness to do the job (section 3.3). In this way, finance has direct influence on people's wish (or not) to work as criminal defence lawyers because it cannot promise the same earnings and (hence) potential lavish lifestyle that large commercial law practices can. However, it also impacts indirectly, by directly contributing to other things (low morale and frustrations with working life - and such frustrations themselves also negatively influence morale further) which also affect lawyers' inclination to work as criminal defence lawyers. Combined, this

\footnotetext{
50 Tribunals, Courts and Enforcement Act 2007, s71.

${ }^{51}$ See Ministry of Justice Judicial Diversity Statistics 2019. The lay criminal judiciary is no panacea for this either, given their own problems with diversity: P Gibbs and A Kirby Judged by Peers? The Diversity of Lay Magistrates in England and Wales (Howard League for Penal Reform, 2014) available at: https://howardleague.org/wp-content/uploads/2016/04/HLWP 6 2014.pdf pp10-11.

${ }^{52}$ Law Society Private practice solicitors' salaries 2016 Practice Certificate Holder Survey (September 2017), Table 7.

${ }^{53}$ Law Society, above n3.

There is, however, ample evidence to suggest severe problems in other publicly funded areas, such as asylum and welfare law, following the huge areas that were simply removed from the scope of legal aid by the Legal Aid, Sentencing and Punishment of Offenders Act 2012. See eg Flynn and Hodgson Access to Justice and Legal Aid: Comparative Perspectives on Unmet Legal Need (Oxford: Hart, 2017). The problem there, however, is a more basic economic issue. Due to cuts in legal aid scope, firms close because their market is simply no longer there: there are no longer "customers" who can pay. This is different to crime, where legal aid is still provided, but at ever dwindling rates for the lawyers involved.

${ }^{54}$ In addition, Law Society, n9, Table 9, does illustrate a financial sacrifice for doing legal aid generally (the more time spent on legal aid, the lower the salary) and data from their (currently unpublished) 2018 Practice Certificate holder survey suggests gross median earnings in the region of $£ 39,000$ (although, again, the low sample size prohibits concluding that average salary has decreased since 2016).
} 
(c) James Thornton 2019. Legal Studies @ 2019 Society of Legal Scholars. Cambridge University Press. This is the author's version of the work. It is posted here for private research and study, not for redistribution. The definitive version is published in Legal Studies (Cambridge University Press), available at: https://doi.org/10.1017/lst.2019.31

multiplying effect has a far more devastating impact on the future of the criminal defence professions than finance would if it only operated directly (ie people not earning as much as they want to).

In 2015, Krieger and Sheldon published a very large-scale research project into what did and did not make lawyers happy. ${ }^{55}$ In line with the findings here, they argued that not having enough money to buy the things that lawyers wanted was not the chief driver of unhappiness in the professions. ${ }^{56}$ Indeed, they found that having lots of money (in itself) did not tend to make lawyers happy anyway. Rather, it was the lack of autonomy, professional respect, low morale etc that made lawyers in their study unhappy (and conversely, even those on lower pay were quite happy if they had autonomy, professional respect etc): "The data contradict beliefs that prestige, income, and other external benefits can adequately compensate a lawyer who does not regularly experience autonomy, integrity, close relationships, and interest and meaning in her work" ${ }^{57}$ Similarly here, whilst many of my interviewees believed their work was interesting and meaningful, and for many provided a sense of camaraderie too, the same cannot be said for autonomy and integrity. Finance, although in itself not a massive bearer on people liking a job, has a stronger influence here because it influences frustrations and morale regarding how that job must be carried out. None of the lawyers responding to this work (or indeed the earlier works cited) seemed unhappy because they did not have enough money in their monthly earnings to live lavishly. Rather what seemed to make them unhappy was the way those lower fees forced them to work (to keep their practices solvent) - often in ways that they found restrictive, distasteful or even ethically uncomfortable. To see this reflected in the (uncontrollable) workings of other actors in the system, such as the courts and CPS (due to similar lack of finance) provides the defence lawyer with a thoroughly disheartening professional existence.

Hence, in terms of the puzzle of why lawyers in other areas (who may not be paid particularly well either) are not in similar crisis, many of these issues are unique to crime. Probate and employment lawyers do not have to contend with an under-resourced CPS; with having to work in frustrating or unethical ways to stay solvent; with being paid late (or never) for work done, with cross-examining small children about their sexual offences allegations (Barrister K); with all-hours visits to the police station when called upon; or with clients who are not infrequently suffering from mental health problems. ${ }^{58}$ Nor do all other areas of law suffer from the heavy use of fixed-fee payment schemes used for criminal legal aid, such that the fee paid often does not reflect the work done. ${ }^{59}$ It may also be something to do with the motivations of lawyers entering particular practice areas. The majority of interviewees, at some stage, discussed their motivations for going into criminal law in the first place. Passion, interest, commitment to helping the innocent and access to justice all featured heavily in their reasons. ${ }^{60}$ Money never did. In contrast, prestigious corporate law firms openly compete with one

\footnotetext{
${ }^{55}$ L Krieger and K Sheldon 'What Makes Lawyers Happy: A Data-Driven Prescription to Redefine Professional Success' (2015) 83 George Washington Law Review 554.

${ }^{56}$ Ibid table at p620 puts money at "Tier 4" and "autonomy, competence and internal motivation/interest" at

"Tier 1". Five tiers in total from most to least important for happiness.

${ }^{57}$ Ibid p623.

58 Those within the criminal justice system are disproportionately likely to suffer from mental health issues, relative to the general population. See G Durkan Mental Health and Criminal Justice (London: Centre for Mental Health, 2016) pp8-9.

${ }^{59}$ For discussion on how these operate on lawyers, see H Sommerlad 'Criminal Legal Aid Reforms and the Restructuring of Legal professionalism' in R Young and D Wall (eds) Access to Criminal Justice: Legal Aid Lawyers and the Defence of Liberty (London: Blackstone, 1996) p307 and, more recently, L Welsh 'The Effects of Changes to Legal Aid on Lawyers' Professional Identity and Behaviour in Summary Criminal Cases: A Case Study' (2017) 44(4) JLS 559, pp575-576 and Thornton (above n27). Welsh found that fixed fees had made lawyers feel "torn" between business needs and client duty. That said, some areas of civil litigation have fixedfee schemes of their own. See also the move towards Fixed Recoverable Costs in civil litigation since 2010: Jackson LJ 'Review of Civil Litigation Costs: Supplemental Report Fixed Recoverable Costs' (Judiciary of England and Wales, 2017).

${ }^{60}$ This was not unexpected given the similar responses in Newman, above n8.
} 
() James Thornton 2019. Legal Studies @ 2019 Society of Legal Scholars. Cambridge University Press. This is the author's version of the work. It is posted here for private research and study, not for redistribution. The definitive version is published in Legal Studies (Cambridge University Press), available at: https://doi.org/10.1017/lst.2019.3

another to offer the highest salaries. ${ }^{61}$ Whilst a somewhat crude comparison (individuals enter specialisms for all sorts of personal reasons), there must be some difference in expectations. Someone who works for a commercial law firm may not necessarily expect to have the opportunity to fight injustice and represent the poor, so the lack of opportunity to do so need not impact morale. On the other hand, someone who goes into criminal law for precisely this reason may have more cause to feel aggrieved when the realities of criminal practice detailed in this article (in terms of the indirect effects of low finance in 3.1 and 3.2, as well as some of the broader systemic issues noted in 3.1) mean they struggle to do so. As Lipsky notes, "the contradiction that they ought to be able to make a difference in clients' lives, but commonly cannot". ${ }^{62}$

\section{5 - CONCLUSIONS}

Of course, there are limitations associated with the methods and sample size of the current study, as with any. Qualitative methods (and the qualitative method of interviewing in particular) have well known strengths and flaws relative to other approaches. For example, there are risks in terms of interviewees reporting in ways which paint themselves in an inaccurately positive light. These limitations must be borne in mind in drawing conclusions. Likewise, in terms of sample size, whilst barrister interviewees were spread out, the solicitor interviews were carried out primarily in the south, (albeit there were some from outside this area) and it nonetheless represents a small percentage of criminal practitioners in England and Wales. These findings are not generalisable across the country. That said, they do show a set of attitudes and experiences, amongst a set of lawyers in various locations, firms and chambers, and at many different levels of experience - which are both remarkably consistent and reflect previous research (mentioned above) in other areas of the country, including that which has used other research methods. Interviewees' willingness to quite frankly discuss things which may appear unethical to the outside observer (particularly some of the comments in the Morale section) would also go some way to mitigating concerns about inaccurately positive reporting.

The combination of systemic issues that make criminal law particularly unpleasant to work in, aggravated directly and indirectly by the effects of financial reductions described here, is potent. As exemplified in section 3.1, it is the nature of the funding system which defence lawyers work within which impacts upon autonomy and integrity of work, by requiring practices to be run in particular ways. Likewise, as we saw in 3.2, the particular way that criminal law work is paid by the LAA and (for barristers) law firms affects morale. It may be that lawyers in probate or employment work (whilst their salary may not always be higher), have a greater sense of autonomy and integrity in their work than their criminal law colleagues and it is this (in line with Krieger and Sheldon's work) which makes the difference. The point could be made more broadly. Those working in professions generally appear much more stressed than other careers, ${ }^{63}$ yet not all of these are in crisis either. It is however, interesting to note that another profession with recruitment and retention issues, school and college

\footnotetext{
${ }^{61}$ Law Society Gazette 'Freshfields hikes NQ pay to £100k as US competition intensifies’ (7 May 2019), available at https://www.lawgazette.co.uk/freshfields-hikes-nq-pay-to-100k-as-us-competitionintensifies/5070202.article

${ }^{62}$ Lipksy, above, n9, p154. See generally, xii "Teachers, social workers, public interest lawyers, and police officers in part seek out these occupations because of their potential as socially useful roles. Yet the very nature of this work prevents them from coming even close to the ideal conception of their jobs. Large classes or huge caseloads and inadequate resources combine with the uncertainty of method and the unpredictability of clients to defeat their aspirations as service workers".

${ }^{63}$ Health and Safety Executive Work Related Stress, Depression or Anxiety Statistics in Great Britain 2018 available at http://www.hse.gov.uk/statistics/causdis/stress.pdf p6.
} 
() James Thornton 2019. Legal Studies @ $\odot 2019$ Society of Legal Scholars. Cambridge University Press. This is the author's version of the work. It is posted here for private research and study, not for redistribution. The definitive version is published in Legal Studies (Cambridge University Press), available at: https://doi.org/10.1017/lst.2019.3

teaching ${ }^{64}$ is reported to suffer from many of the same issues in terms of autonomy and integrity that criminal lawyers face (although it is vastly beyond the scope of this article to speculate the mechanism for how those issues arise - is it Ofsted? Is it school financing? Is it workload?). ${ }^{65}$ The fact remains that the profession reports a large number of concerns beyond the pay they receive being, in their view, inadequate to account for these problems, many of which relate strongly to Krieger and Sheldon's list. My answer to the "puzzle" is therefore that it is not the direct result of cuts in finance themselves alone (which many professions and legal specialisms must deal with) which make the publicly funded criminal defence professions unsustainable, but rather, the indirect effects these have in terms of how the job must be done.

Newman's study into the working practices in three defence firms found that lawyers, when interviewed, claimed to hold very client-centred views, but those same lawyers in observation did not treat clients very well: "they could talk the talk, but not walk the walk". ${ }^{66}$ However, Newman struggled to reconcile this disparity. Subsequent papers spoke of lawyers being "alienated" and then "neurotic" workers, taking their frustrations out on their clients. ${ }^{67}$ Another recent (co-authored) paper, however, focused on a much more measured theme: vulnerability. Lawyers did not match up in practice to how they suggested they behaved in interview because they themselves were vulnerable: ${ }^{68}$ "they no longer feel able to do their jobs to the best of their abilities and thus compromise their standards in order to get by in a chastened financial climate." ${ }^{69}$ On the basis of the present study, it may be that the disparity Newman observes is down to the above themes operating with his lawyers too. Interviews revealed what his lawyers wanted to be/do. The ethnography revealed how they did not do so, and I argue that they would struggle to do so given the financial context within which they must work. This tension between what one values and wants to do vs how one actually has to do criminal defence in order to make a living leads to great frustration and low morale. Newman did not seek to blame finance for this, rather he blamed a culture shift away from client-centered values. ${ }^{70}$ However, the point I have sought to illustrate throughout here is that finance cannot be looked at only in direct terms. True, the mere fact that (if their salary went up) a lawyer could buy an expensive car may not change a working culture, but finance operates indirectly too. It contributes to the way the job must be done and to morale in doing that job. In changing that, finance is crucial - as an indirect driver of morale and frustrations. Currently, those who cannot stomach this, leave, and the current study (alongside the cited reports from the professional associations) suggests that leave many will. In this way, whilst financial issues can be blamed for recruitment and retention issues, it is important to understand how this operates indirectly as well as directly. On that basis, it may well be that a relatively small increase in funding could have a disproportionately positive effect in terms of lawyer morale, because although it would not allow defence lawyers to experience a champagne lifestyle, it would go some way to alleviating the concerns raised above - which are in many ways more impactful concerns. As it stands though, the profession, as we know it, appears unsustainable.

\footnotetext{
${ }^{64}$ See eg Department for Education Initial Teacher Training Census for academic year 2018-2019 (2018) showing missed recruitment targets in many subjects for new entrants and Department for Education Teacher Recruitment and Retention Strategy (2019), Sector Bodies Foreword: "Over a number of years, it has become increasingly difficult to recruit and retain staff of the calibre required."

${ }^{65}$ C Savill-Smith Teacher Wellbeing Index (Education Support Partnership, 2018).

${ }^{66}$ Newman, above n8.

${ }^{67}$ Above $\mathrm{n} 18$ and n19.

${ }^{68}$ R Dehaghani and D Newman " "We're vulnerable too": an (alternative) analysis of vulnerability within English criminal legal aid and police custody' (2017) 7(6) Oñati Socio-legal Series 1199.

${ }^{69}$ Ibid p1204.

${ }^{70}$ Newman, above n8, pp158-159.
} 